\title{
The Relationship between Authority and Authenticity in the Laozi: Employing $W u$ 無 as a Philosophical Framework
}

\author{
Sharon Y. Small \\ Department of Philosophy, East China Normal University, 500 Dongchuan Road, Minhang, Shanghai 200241, \\ China; ssysmall12@gmail.com
}

Received: 6 December 2018; Accepted: 22 January 2019; Published: 25 January 2019

\begin{abstract}
W u$ 無 is one of the most prominent terms in Ancient Daoist philosophy, and perhaps the only term to appear more than Dao in both the Laozi and the Zhuangzi. However, unlike Dao, $w u$ is generally used as an adjective modifying or describing nouns such as "names", "desires", "knowledge", "action", and so forth. Whereas Dao serves as the utmost principle in both generation and practice, $w u$ becomes one of the central methods to achieve or emulate this ideal. As a term of negation, wu usually indicates the absence of something, as seen in its relation to the term you 有__ "to have" or "presence". From the perspective of generative processes, wu functions as an undefined and undifferentiated cosmic situation from which no beginning can begin but everything can emerge. In the political aspect, $w u$ defines, or rather un-defines the actions (non-coercive action, wuwei 無為) that the utmost authority exerts to allow the utmost simplicity and "authenticity" (the $z i$ 自 constructions) of the people. In this paper, I suggest an understanding of $w u$ as a philosophical framework that places Pre-Qin Daoist thought as a system that both promotes our understanding of the way the world works and offers solutions to particular problems. $W u$ then is simultaneously metaphysical and concrete, general, and particular. It is what allows the world, the society, and the person to flourish on their own terms.
\end{abstract}

Keywords: Daoism; Laozi; authority; authenticity; wu

\section{Introduction}

Chapter 11 of the Laozi $^{1}$ uses three different images ${ }^{2}$ to explain the relationship between $w u^{3}$ and you有 and sums it up as the relationship between value and utility. In this Chapter wu and you are equally necessary in constructing the world as we know it.

Thirty spokes converge at one hub, but the utility of the cart is a function of the nothingness $(w u)$ inside the hub. We throw clay to shape a pot, but the utility of the clay pot is a function

1 This paper uses the transmitted version of the Laozi as this is the main version which has been handed down from generation to generation for almost two millennia. References to other versions are made where necessary.

2 I do not elaborate on the discussion of images in the Laozi, for a philosophical interpretation of images, see (Moeller 2006) Moeller, Hans-Georg. The Philosophy of the Daodejing. New York: Columbia University Press.

$3 W u$ in the Laozi and in Ancient Chinese Philosophy in general has been translated and interpreted in various ways, ranging from a simple "non" to a more complex "nonbeing". In this paper I propose two routes for translation depending on the broader context. First, I do not support the translation of you as "Being" due to the heavy philosophical connotations of "being", rather as something like "presence". In a relation to you I maintain in this case that wu can refer to the "absence of" or "non-presence", which indicates that $w u$ does not mean "nothing" as in "nothingness" but rather does have a function. In other contexts, while understood as an adjective, $w u$ has a much broader interpretation as it modifies the noun or verb following. 
of the nothingness inside it. We bore doors and windows to make a dwelling, but the utility of the dwelling is a function of the nothingness inside it. Thus, it might be something (you) that provides the value, but it is nothing that provides the utility.

In general, when we look, experience, and contemplate about the world our attention is easily directed towards "what is there". You 有, meaning "to have" or "presence", are the things we notice, the obvious, but rarely do we think of "what is not there". Here, the author of the Laozi reminds us that is precisely what is "not there" that allows the things that "are there" to function. The author tells us to direct our attention to this "absence"-it is due to absence that presence is enhanced. However, enhancing presence is not the core purpose of advocating a philosophical system that equally emphasizes both what is there and what is not-a full account of their interaction brings to a greater realization into how the world functions. Even though the passage above describes phenomena in the world and can be directed towards an ontological understanding rather than a metaphysical explanation on the level of Dao, ${ }^{4}$ it shows us the constant mutual interaction between you and wu. Although the example here is concrete, this relationship of mutual interaction can be further projected unto the metaphysical function of the cosmos.

To understand the full encompassment of $w u$ we have to go a step further and look at $w u$ in its contexts, or as Hall and Ames call it, the "wu-forms". ${ }^{5}$ These include many familiar concepts such as wuwei ("non-coercive action which accords to the particular focus of things"), wuzhi知 ("knowing without resort to rulers or principles"), wuyu欲 (desiring which does not seek to possess or control its "object") and so forth.

According to Hall and Ames, Daoism expresses its deferential activity through wu-forms. In other words, an authority becomes authoritative by giving way to the self-development of the people of things. In their articulation, wuwei involves the absence of any course of action that would hinder or interfere with the particularity of things or people, they are nonassertive actions that allow their self-soing. Wuzhi then is the absence of knowledge which is dependent upon ontological presence, or in other words, an unchanging reality behind appearance.

According to the Daoist cosmological view, there is no presupposed single-ordered world. Although Dao generates the world, ${ }^{6}$ it is not its creator in the strict sense that it is not an all-powerful divine being or an all-powerful initiator. Dao "gives things life yet does not manage them, it assists them yet makes no claim upon them, it rears them yet does not lord over them". Dao, as something that does not manage, claim or lord, allows the world to emerge as a collaboration between Dao and particular beings or events. In this sense, there is no 'creation' which has a beginning and an end, rather an ongoing generative process wherein the world is ever renewing. Dao, as a concrete and practical way, serves as the ideal the sage-ruler emulates and follows. In this meaning, just as Dao

4 The distinction between "ontological" and "metaphysical" refers to two different levels of understanding Dao. The former refers to a concrete reality, while the latter is more abstract in the sense that it incorporates the "cosmological" meaning of Dao, i.e., Dao as a generative force and the beginning of the cosmos.

5 See introduction to Ames and Hall translation of the Daodejing (Ames and Hall 2003, pp. 36-53). In this paper, I propose to call it "wu-constructions" instead of "wu-forms". In my view, there is a slight difference between the two terms. Whereas the term "forms" may have the connotations of something fixed, inflexible and independent, the term "construction" is understood as something interdependent that is always in relation to something else. In the framework of this paper, $w u$ is not interpreted as a fixed ontological entity, but rather as a flexible term which comes to full realization through its relationships. In the cosmological section of this paper, $w u$ is always understood in its relation to you h and Dao. In the section on political philosophy, $w u$ is realized through the different terms attached to it (such as action, knowledge, and desires) and the parallel relation between these constructions to $z i$ 自(self).

6 The most well-known cosmological statement in the Laozi appears in Chapter 42: "Dao generates the one, the one generates the two, the two generate the three, the three generate the myriad beings." In my view, the concrete entities the numbers 'one, two, and three' refer to remains a mystery-as any concrete interpretation will inevitably disregard any other option. Furthermore, all interpretations given throughout the long history of commentaries that we can trace as far back as the Post-Han commentator Wang Bi王弱, have done more to show us something about the philosophy promoted by the interpreter rather than an 'original meaning' of the text. Nevertheless, the fact that the options are endless, comes to show that regardless of the concrete meaning of 'one, two, and three', we begin with Dao (as a generating force) and 'end up' with multitude. 
does not manage, claim or lord, the ruler does not dominate the people but rather gives them the right conditions for them to develop and flourish on their own. Wuyu, translated by Hall and Ames as "objectless desires" is then associated with enjoyments which are possible without the need to define, possess, or control. This desire is based upon a non-coercive relationship with the world and a 'mirroring' understanding of it (wuzhi). This type of desiring does not desire to own, control or consume, but simply to celebrate the authenticity $\left(z i\right.$ 自) of the beings. ${ }^{7}$ In other words, it is deference.

Following this introduction, the paper is composed of two sections and a conclusion. In the first section I discuss $w u$ on the cosmological and generational level. $W u$ is not to be understood as a fixed ontological category, but rather as an "interdependent explanatory category". ${ }^{8}$ Although both the terms you and $w u$ appear before the Laozi was composed and compiled into its current forms, ${ }^{9}$ placing them in philosophical discussion and context is something that begins with the Laozi. ${ }^{10}$ In the first section, $w u$ is mainly understood in its relation to you and Dao. ${ }^{11}$ In the section following we see the concrete and practical implications of $w u$ as employed in the political domain. The analysis of concepts such as wuwei, wuming 名, wuzhi, wuyu, and wushi事 become the focus of the discussion. As wu is understood in its relation to you and Dao in the first part of this paper, in the second section I pair $w u$ with $z i$ 自(self), showing a parallel and interdependent relation between the two types of constructions. In the Laozi, the metaphysical (abstract) is always in relation to the concrete, the ideal with practice. Thus, there is no sole independent existence. Dao always functions in relation to the beings and this relationship is mirrored by the parallel between the ruler and the common people. Furthermore, $w u$ and its relationships (either with you or with zi) ties the cosmological and metaphysical to the practical and concrete (as expressed in the political philosophy offered by the Laozi). Thus, the wu constructions and their parallels offer a philosophical system that unites the ways of the world with the ways of human beings. On one level, it offers an explanation to how the world works and, on another level, offers methods to function well in the world of human beings.

\section{Dao, $W u$, and You}

Dao, you and $w u$ are the most fundamental concepts for the Laozi and Pre-Qin Daoist philosophy. The earliest evidence for this statement is found in the Tianxia天下Chapter of the Zhuangzi子:

建之以常、、有, 主之以太一12

system constructed upon constancy, ${ }^{13} w u$ and you, rooted upon the grand one.

7 The discussion of 'authenticity' in this paper does not refer to the Western philosophical (especially in the philosophy of ethics) 'baggage' prescribed to this word over the last few centuries, rather refers to the Greek origin of the word 'authentikós' meaning 'originally, primary, at first hand', which is also equivalent to 'authént(ēs)': 'one acting on one's own authority'. This definition of 'authenticity' is closer to the implications of 'self- $\mathrm{X}$ ' $(z i$ 自X) as prescribed by the Laozi.

8 (Ames and Hall 2003, p. 91).

9 The earliest written version of the Laozi known to us today is the Guodian郭店 bamboo version (fourth century BCE) excavated from a tomb which presumably belonged to the tutor of the crown prince, meaning that this text might have first appeared in written form during the historical period known as the 'Warring States period'. In general, the assumption is that before ancient texts appeared in written form they were circulated orally, meaning that the Laozi might be based on an oral tradition preceding the first written versions by hundreds of years. If this is the case, we cannot be sure what the 'original' version was, who 'authored' it or when it first came into formulation. However, the terms $w u$ and you in their earliest forms appear on oracle bones which are dated to the Shang (商) Dynasty (1600-1046 BCE), meaning that they were not new terms by the time the Laozi came into being. In general, they do not incorporate a philosophical meaning prior to the Laozi. In the Zhou Book of Changes (Zhouyi周易) for example, they merely come to state the presence or absence of auspicious or ominous situations, which was probably the main function of these terms in early divination practices.

10 (Wang 1991) Wang Bo 王博. Laozi zhexue zhong dao he you wu de guanxi shitan老子哲学中“道”和“有”、“无”的关系试探. Zhexue yanjiu哲学研究1991/8.

11 This is a relationship that has been previously discussed by commentators throughout history as well as modern scholars such as Wang Bo王博1991/8 (Wang 1991), Feng Youlan冯友兰. (Feng 1987) Zhongguo zhexue shi dagang 中国哲学史大 纲Shangwu yinshuguan 商务印书馆.

12 We can understand Taiyi 太 一 here as a term indicating Dao. See (Wang 1991).

13 Chang or Heng 恒are interchangeable terms indicating constancy or permanence. However, in the Daoist context, this permanence is not a fixed ontological entity, it is a concept that incorporates transformations and changes. The change of 
The terms chang 常, wu, and you 有are key terms in the Laozi that not only describe Dao but are essential components of it. Unlike most philosophical systems that focus either on being or non-being, on presence or on absence, the uniqueness of the philosophy presented in the Laozi is its ongoing (chang) interaction between $w u$ and you. We cannot understand the world and all its aspects if we do not understand both what we can perceive and what we cannot perceive. The text constantly reminds us to pay attention to both sides of the coin-not only to what is there, but also to what is not there. This is something we find in the very beginning of the text as the opening Chapter of the transmitted version of the Laozi which begins with a metaphysical discussion on Dao:

Dao that can be spoken of is not the constant dao. Names that can be designated, are not constant names. With an absence of names, the world begins, with the presence of names, all beings are mothered. Therefore, while consistent in the absence of desires one can observe its subtleness, while consistent in desires one can observe its boundaries. Those two, simultaneously emerge but differ in name, both are called profound. Profound and abstruse, it is the gate to all subtleties.

In this passage the subject is Dao. It offers us an explanation of Dao and its functions and not about the beings (wanwu物). The "wu-constructions" along with the "you-constructions" occur in two instances and tell us first about the generation of a world and second about the ways in which Dao function and how to observe it. The absence of names (wuming 名) along with the presence of names (youming有名) have cosmological significance. Both are aspects of Dao and together they generate the world as we know it. ${ }^{14}$

In past research wuming was considered to be Dao due to the textual evidence that tells us that Dao has no name. ${ }^{15}$ But I argue here that wuming is not the sole aspect of Dao-it is the starting point and the ending point in the cyclical movement of Dao. Dao, although frequently residing in the nameless, includes aspects that do have a name.

Chapter 25 serves but as one example:

There is a thing - it came to be in the undifferentiated, generated before heaven and earth. What stillness! What emptiness! Alone it stands fast and does not change. Moving about in cycles and never endangered, it can be mother to the world. I do not know its name, I style it as Dao. If forced to name it, it is called grand. Grand means to proceed, to proceed means distance, distance means return. Therefore, Dao is grand, heaven is grand, earth is grand, the king is also grand. In the land there are four grandees, the king occupies one of them. Humans emulate earth, earth emulates heaven, heaven emulates Dao, Dao emulates the natural course of all.

In relevance to our discussion, we can draw a few points from this passage. First, the movement of Dao, as also described in Chapter 40, is cyclical. It is a never-ending process. Far-fetching, it again returns $(\mathrm{fan} 反)^{16}$ to the beginning- to the state of $w u$. Chapter 14 tells us exactly what it returns to,

the seasons is constant, but not one season is permanent. Linguistically, it does not hold just one designated fixed definition and can be understood or translated in many ways. As a derivative of permanence, I elsewhere describe it as 'ongoing'.

14 It can be argued that wuming comes before youming, while a hint to this assumption is derived from the etymology of the words 'beginning' (shi始) and 'mother' ( $m u$ 母).

15 Chapter 32 opens with the statement "Dao is constantly nameless". There are two points we must pay attention to for a reading that further resonates with the rest of the text. First, all depends on how we understand the word chang (or heng as it appears in the earlier versions). If we understand it as designating a fixed and constant ontological entity, then we arrive at a meaning that tells us that Dao is one-sided and nameless. However, if we understand it as something which incorporates a mode of transformation and change, we have a more open reading. Another point is that we ought to read the Chapter from beginning to end along with other Chapters in the Laozi. As the same passage tells us—at some point there are names: "When we start to regulate the world we introduce names. But once names have been assigned, we must also know when to stop. Knowing when to stop is how to avoid danger."

16 This fan反 character is a phonetic loan for 返 (fan) which means 'return' and not 'reverse'. See (Wang 2019) Wang Zhongjiang王中江: “Abnormalities and Return: An Exploration of the Concept Fan 返 in the Laozi". Religions. Vol. 10/1, 2019. 
saying "returns to the state where there are no beings". Next, the passage tells us that in certain circumstances, we can give it a name. As the mother of the world we do not know its name, but we can give it a style name: Dao, and if forced to further give it a designated name-we can call it 'grand' (da大). In the case of $w u$-the beginning and end of the cycle-we cannot give it a name, we can only style it. However, the rest of the ongoing cycle-the you part, we can give it a name, and thus we call it grand. Being in the state of you it does not stop, it proceeds, distances and finally returns to $w u$.

Chapter 40 assists in further advancing our understanding of Dao as an ongoing cycle and the way $w u$ and you interact in this endless process of generation:

Returning is the movement of Dao; weakening is its function. All beings in the world generate from you, you generate from $w u .{ }^{17}$

This passage tells us again that the world and all beings within it are generated from the movement and function of Dao. The text tells us that everything is generated from you and you is generated from $w u$, which gives us a sense that $w u$ is prior to you, at least in the sequence of time and generation-but is this really the case? A proper reading of the text leads us to contextualization-we ought to read this passage in light of other passages and not as an independent entity. Chapter two tells us that "wu and you give rise to each other". There are two routes we can follow to achieve a reading where both passages resonate with each other. The first route tells us that we are speaking of two different subjects: in Chapter 40 the subject is Dao, in Chapter 2 the subject is the beings. Chapter 40 should be understood in a metaphysical sense, or to use the Chinese term, in the sense of "above the forms" (xing er shang形而上) and not in the ontological or epistemological sense. In this manner, Dao moves in cycles and thus its starting and ending point are the same- both are $w u$, while the rest of the generative process occurs in the state of you, as seen in Chapter 42 which says

道生一, 一生二, 二生三, 三生物

Dao generates one, one generates two, two generates three, three generates the myriad things and beings.

Unlike a process of creation that has a creator, this process of generation is ongoing and ever occurring, the world is ever new and renewing. The Laozi extends this cosmological and metaphysical level to all beings in the world-and in turn it becomes the course in which the ruler rules and the person cultivates. Therefore, the metaphysical becomes the basis for the concrete-and just as $w u$ and you are always tied together-so are the realms of cosmology and human beings.

The second route which is inherently tied to the first but goes beyond it, is that we are to understand the two passages on different levels. While Chapter 2 is epistemological, we see logical developments. We are told that "everyone in the world knows the beautiful as the beautiful, thus there is ugliness", meaning that the activity of knowing brings about categories and distinctions. This is not a cosmological statement, but a logical and epistemological one. Therefore, when it says that "wu and you give rise to each other", the text is referring to sets of corresponding opposites as we see in the consecutive phrases which include terms such as difficult and easy, long and short, high and low, and so forth. These corresponding opposites are the only way we can consciously define phenomena in the world, and they belong to the realm of what Laozi calls "on behalf of learning" (weixue) and not

17 Our reading of this passage will radically differ if we look at the Guodian 郭店 version. In the Guodian version the phrase is written as such: "All beings/things in the world emerge from you and wu". The Guodian version tells us that on the cosmological level of generation $w u$ and you are equal, one is not prior to the other, it is the function of both together that create the myriad things. This reading resonates with both Chapter $\mathrm{w}$ and Chapter 11 quoted above. Both wu and you are phases of Dao, without preference to one over the other. Historically speaking, it was not until the Wang Bi and the Xuanxue school in the Wei-Jin period that $w u$ was elevated over you and thought to come before in the sequence of time. See (Chen 2015) Chen Guying 陈鼓应: Zhongguo zhexue de chuangshizhe Laozi xinlun中国哲学的创始者一一老子新论. Beijing: Zhonghua shuju中华书局85: 88-90. 
to the realm of Dao (wei dao道). Whether this is a desirable outcome or something we should rid of is another question that shall be dealt with elsewhere.

Returning to the opening chapter of the Laozi, there is another set of the wu-you pair that deserves our attention. The text says: "while consistent in the absence of desires, one observes its subtleness, while consistent in the presence of desires, one observes its boundaries". When talking about desires, our intuitive understanding is that the subject who desires is a living being (whether human or animal). However, the subject of this entire passage is Dao, not beings. The key term in this phrase is the verb "to observe". While the passage describes the metaphysical realm of Dao, we are told that we can observe two different aspects of it—-both the one that desires and the one that does not desire. Neither of them is superior to the other-they are equal aspects of Dao, one resides in the realm of $w u$ and the other in the realm of you. The $w u$ aspect offers us subtleties and the you aspect offers restrictions. Both are necessary components of Dao, both are essential for generation of the world and all beings and things in it.

We conclude this section with the notion that there are two different levels of understanding in the Laozi just as there are two different aspects of Dao. The statements that "Dao is $w u^{\prime \prime} 18$ and "Dao is you"19 are both correct, and both aspects are necessary for development. This development however is not only the development of the cosmos, but as we will see in the following, it also involves the development of society.

\section{The $W u()$ and $Z i($ 自) Constructions}

Although only eleven out of 101 wu constructions in the Laozi are paired with wei, wuwei as a concept has received and continues to receive the most attention out of all $w u$ constructions in early Daoism. In some modern interpretations, wuwei is even connected to neuroscience and "flow theory"20_describing a way of experiencing, or "just being" in the world. ${ }^{21}$ Not denying the importance of wuwei, in this section we view wuwei as a mode of action intended to describe the way Dao works in relation to the myriad beings and things, or the way the sage ruler, in relation to the common people, should govern his kingdom. ${ }^{22}$ However, we do not arrest with the term wuwei, we go beyond this singular $w u$ construction and discuss other $w u$ constructions such as wushi, wuyu, wuming, and others. The purpose is not to offer a new understanding of wuwei, but to achieve a broader sense of those $w u$ constructions in relation to the $z i$ constructions. In other words, the purpose is to analyze the relationship between the sage ruler and the common people through the relationship between Dao and all beings and things.

The case of ziran (自然) is similar. Zi 自is a term that occurs 33 times in the Laozi, mostly interpreted and translated as "self". However, even though only five of those appearances come together with the word ran然, the term ziran 自然 became the focus of many studies on the Laozi and Ancient Chinese

18 Hu Shi胡适 and Feng Youlan 冯友兰 maintain that Dao is wu. See (Hu 1987) Hu Shi: Zhongguo zhexue shi dagang中国哲学史 大纲, vol. 1. Beijing: Shangwu yinshuguan商务印书馆, p. 58; and (Feng 1959) Feng Youlan: Laozi zhexue taolun ji老子哲学讨 论集. Beijing: Zhonghua shuju中华书局.

19 Yan Lingfeng 严灵峰maintains that Dao is you. See (Yan 1983) Lao Lie Zhuang sanzi yanjiu wenji老列庄三子研究文集. Guoli bianyi guan zhonghua congshu bianshen weiyuanhui国立编译馆中华丛书编审委员会.

20 "Flow" is a psychological theory proposed by Mihaly Csikszentmihaly. See (Csikszentmihaly 2014) Csikszentmihaly, Mihaly. Flow and the Foundations of Positive Psychology: The Collected Works of Mihaly Csikszentmihalyi. New York: Springer Press.

21 For an example of this phenomenon see (Slingerland 2003) Slingerland, Edward, Effortless Action: Wu-wei as Conceptual Metaphor and Spiritual Ideal in Early China. Oxford: Oxford University Press; and (Slingerland 2014) Trying Not to Try: Ancient China, Modern Science, and the Power of Spontaneity, New York: Broadway Books Press.

22 Another interesting and inspiring analysis of wuwei is found in Chad Hansen's book A Daoist Theory of Chinese Thought, where he analyzes the concept through emphasizing both the linguistic and social function of wei: "To wei is to assign something to a name category in guiding action ... it focuses less on the action than the evaluative categorizations that guide actions ... For Laozi, wei signals socially induced, learned, patterns of response-the opposite of autonomous or spontaneous response" (Hansen 1992, pp. 213-14). This interpretation is insightful due to the definition of wei which can very well be understood as something that hinders our 'autonomous response', however, it ties wuwei together with ziran, instead of understanding them as 'parallel'. My claim is that wuwei is something that Dao or the ruler do, while ziran refers to the modes of the beings, things and people. Thus, it is not the people who ought to 'wuwei'. 
philosophy, especially Daoism. ${ }^{23}$ Translated as 'self-so' or 'spontaneity' the term 'ziran' has mainly be understood to indicate a natural condition, a mode of action that accords with our 'natural self'. ${ }^{24}$

The two, wuwei and ziran, are often linked in the attempt to create a theory prompting spontaneity thereby producing a spiritual reading of Daoist materials, a reading that is open to all and can be achieved by the layman seeking revelation. ${ }^{25}$

Although I do not wish to remove the spiritual reading from Daoism or the Laozi, as it is a philosophy that later developed into a religion incorporating spirituality for practitioners, I do maintain that the philosophy in the Laozi was initially a philosophy concerning Dao, intended for the ruling elite in general and the ruler in particular. Furthermore, if we take a closer look at the occurrences of the ' $w u^{\prime}$ ' and ' $z i$ ' constructions, we find that (A) wuwei and ziran are not the most prominent of those constructions and (B) the subjects of the ' $w u^{\prime}$ constructions are for the most part either Dao or the ruler, and the subjects of the ' $z i^{\prime}$ ' constructions are the myriad beings and things and the common people. ${ }^{26}$ Here, I argue that in relation to one another, the ' $w u$ ' and ' $z i^{\prime}$ ' constructions offer a political philosophy based on authority (of Dao or the ruler) and authenticity (of the things and common people). In the following discussion we see how the $w u$ of Dao and the ruler allow the $z i$ of all beings to flourish on their own accord.

We first encounter the $z i$ construction in Chapter 7 of the Laozi:

The heavens are lasting and the earth enduring. The reason the world is able to be lasting and enduring is because it does not live for itself. Thus, it is able to be long-lived. It is on this model that the sages withdraw their persons from contention yet find themselves out in front, put their own persons out of mind yet find themselves taken care of. Isn't is simply because they are unselfish that they can satisfy their own needs? (Translation by Hall and Ames, p. 86).

This 'zi-construction' talks about heaven and earth 'auto-generating' (zisheng自生), translated above by Hall and Ames as "live for itself". The chapter takes a step forward and applies this model to the sage-where it uses the terms 'self/body' (shen 身) and 'personal desires' (si 私). Although the subjects that 'zi-sheng' 自生 are heaven and earth, ${ }^{27}$ the sage ruler must learn from these cosmological phenomena to become the ultimate authority in the world. In general, the connection between cosmology and society, universe and politics is common to all thinkers in ancient China. This is apparent as early as the Shang oracle bones where 'heavens', 'ancestors', and 'spirits' served a guideline for the ruler's actions through divination. In more explanatory forms, we see examples for

23 For example, see (Lai 2007) Lai, Karyn. "Ziran and Wuwei in the Daodejing: An Ethical Assessment". Dao 6: 325-37.

24 Those interpretations are problematic in many ways, especially when the so-called subject is not a living being but can refer to great things such as heaven and earth. Philosophically speaking, heaven and earth cannot have a self, for this would cause several contradictions in what we call the natural world. The word 'self' is an isolating term, one that constructs and promotes individualism - which would lead us eventually to go against a philosophy that promotes the relational, whether this relational is in the context of human beings (relationships among humans, i.e., society) or within the wider context of relation to the world and everything included within the cosmos. In Chinese, the term zi originates from the image of a nose-which brings to mind two connotations, neither related to the English term of the 'self'. The first connotation is physical, and if it is to mean self-then this self should be understood as the personal body, not the indication of a 'soul' or 'ego' as the English term incorporates. Second, the nose is something we use to breathe and to smell, thus it is a sensatory organ. The two connotations put together give us a corporeal understanding, something that connects us to the natural world rather than isolates from it. Being ' $\mathrm{zi}^{\prime}$, we become an integral part of the universe. I suggest that the term 'self' as we understand it in English would be more suitably understood as 'si私' in Ancient Chinese, a term which indicates personal desires and incorporates the 'mental/psychological realm' as opposed to a more physical one.

25 However, ziran has less than half of the appearances of wuwei in the Laozi-this suggests that ziran does not refer to Dao or the ruler. In a similar matter, the words Dao, ruler, sages and the personal subject ' $\mathrm{I}$ ' have more appearances than 'wanwu' (物) or ' $\mathrm{min}^{\prime}$ (民). Thus, we can conclude that the focus of this book is directed at the ruler and not at the common people.

26 See (Wang 2010) Wang Zhongjiang 王中江. Dao yu shiwu de ziran: Laozi “daofa ziran” shiyi kaolun道与事物的自然: 老子“道法 自然”实义考论. Zhongguo zhexue中国哲学 2010/8.

27 Heaven and earth do not have generative powers. Although they are cosmological phenomena, they are not the forces that generate this world, rather things (wu物) that are generated by Dao. 
this in texts as early as the "Book of Documents" (Shangshu尚) and the "Speeches of Zhou" (Zhouyu周) recorded in the "Sayings of the State" (Guoyu). ${ }^{28}$

Just as the heavens and earth do not live for their own accord, the sage ruler rules for the people and not for his own accord. It is by putting his own needs last that his greater needs are taken care of, by placing his personal desires in the back his real desires are satisfied. On the cosmological level, Dao does the same thing. Although Dao generates everything, it does not possess the beings, rather lets them live on their own accord:

Dao give things their life, and their particular efficacy is what nurtures them. Events shape them, and having a function consummates them. It is for this reason that all things honor Dao and esteem efficacy. As for the honor directed at Dao and the esteem directed at efficacy, is not a result of being ordained, but of being consistent in its own self-so (ziran 自然). Dao gives them life and nurtures them, rears and develops them. It brings them to fruition and maturation, nourishes and guards over them. Dao gives things life yet does not manage them. It assists them yet makes no claim upon them. It rears them yet does not lord over them. It is this that is called profound efficacy (xuande 玄德). (Chapter 51)

This chapter gives us a detailed description of the relationship between Dao and the myriad things. Dao does not ordain the beings, but rather lets them flourish on their own. The key to this chapter is that it tells us that Dao does not ordain the myriad things and beings-the reason they honor Dao and esteem efficacy is because they can be themselves on their own. This chapter tells us that the utmost authority belongs to Dao, it gives things their life, nurtures them, shapes them, and consummates them. The authority of Dao is manifested through the honor and esteem directed towards it, while the authenticity of the things is manifested through their ability to be their own self-so (ziran).

As the philosophy presented in the Laozi was initially directed at the governing elite, the cosmological model was applied to the ruler through his parallel position to Dao, while the role of the beings and things in nature was paralleled to the common people. The ruler should thus abide by this paradigm, and by doing so he achieves the utmost authority among his subjects. However, this authority is not merely established on the ruler emulating the cosmic function of Dao but comes hand in hand with allowing the authenticity of the people. As Dao is not in void but always in relation to the beings and things ( $w u$ 物), the ruler is not a separated individual being, rather is always in relation to the subjects ruled. In this sense, the authority of the sage-king comes from two different aspects. On one hand it comes from him being able to realize Dao and how it functions in relation to the myriad things, and on the other hand, it comes from the people. The ideal ruler according to Daoism is not a tyrannical ruler-he does not possess the people, he does not make a claim upon them, nor does he manage them, he simply, through emulating this dual relationship between Dao and the myriad things, brings them to a state where their basic needs will be taken care of and they will submit to his authority willingly. Submitting willingly to authority can occur only in a state where people can reach full authenticity where they can act on their own authority. Thus, the ruler nurtures the people, rears them, develops them, brings them to fruition and maturation, nourishes them and guards over them. With these conditions as the base, the people can then realize themselves in the sense that they are safe, their needs are taken care of, and all that is left for them to do is develop in their own natural direction.

While this chapter does not have the term 'non-coercive action' (wuwei), it contains this idea through the saying 'not a result of being ordained'. That is, Dao does not ordain, does not force the things to behave in certain ways, yet lets them occur on their own. The ruler, being the utmost

28 Examples are manifold, to cite them would take us off the main text in discussion herein. For brief and informative account of the connection between cosmology and politics in ancient China see (Rosemont 2006) Rosemont, Henry, Jr. ed. "Explorations in Early Chinese Cosmology". Journal of the American Academy of Religion Studies L/2: 11-65. 
authority over the people, must learn not to 'order' (ming 命) them, but as this chapter says, allows them to 'be consistent in their own self-so' (chang ziran常自然). While allowing them to be as such, they automatically honor and esteem (the ruler).

Chapter 32 makes the parallel between Dao and the myriad things and the ruler with the people more explicit:

Dao is constantly nameless. Although in this unworked state it is of little consequence, no one in the world would dare to condescend to it. Were the nobles and kings able to respect this, all things would defer on their own accord (zibin 自). To the heavens and the earth would come together to send down their sweet honey, and without being so ordered, the common people would see that it is distributed equitably on their own accord (zijun 自 均). (Chapter 32)

As this chapter makes the connection between the utmost cosmological authority (Dao) and the utmost social authority (the ruler) clear, it also introduces two more ' $z i$-constructions': 'to defer on their own accord' (zibin 自) and 'to distribute equitably on their own accord', (zijun 自均).

These zi-constructions can only occur in a situation where something is absent. Absence is not to be understood in negative terms, it is due to this absence that things can function.

In this chapter, we have two cases of absence: first, it tells us that Dao has no name, which if we extend to the ruler we can understand this as the ruler not governing for the sake of his name (reputation), but for the sake of the people. The second is the absence of orders (mo zhi ling莫之令), that means that in the government of the sage ruler, who maintains the nameless and simplicity of Dao, there is no need to give orders, as the people will see to the equal distribution of the goods presented by heaven and earth. In this state of political simplicity, the subjects defer to the authority of the sage-ruler on their own. Similarly, Chapter 37 opens with a statement on Dao and then tells us that the nobles and kings ought to maintain and respect the way in which Dao works:

Dao constantly does things non-coercively and nothing is left undone. ${ }^{29}$ Were the nobles and kings able to respect this, all things would be able to develop along their own lines (zihua 自 化). Having developed along their own lines, were they to desire to depart from this, I would realign them with a nameless scrap of unworked wood. Realigned with this nameless scrap of unworked wood, they would leave off desiring. In not desiring, they would achieve equilibrium, and all the world would be properly ordered of its own accord (ziding 自定). (Chapter 37)

Being in a mode of non-coercive action and letting the things or the people develop and prosper along their own lines is the highest moral ideal in Daoism. This moral ideal is indeed very different from the Confucian moral order which is based on many virtues (de德) and systemized ritual propriety. The Laozi on the other hand, defies this ethical system which is based on authority and its hierarchal subordination by preferring a more flexible relationship between the ruler and the people which allows both the authority of the ruler and the authenticity of the people. Thus, while Chapter 57 lays out a Daoist theory of ethics, Chapter 38 shows us that the ethical order as established in other systems of thought is one of moral degeneration that departs and distances us from Dao:

It is because the most excellent do not strive to excel that they are of the highest efficacy. And it is because the least excellent do not leave off striving to excel that they have no efficacy. Persons of the highest efficacy neither do things coercively nor would they have any motivation for doing so. Persons who are most authoritative (ren) do things coercively and

29 The Mawangdui 王堆 version of the Laozi has “Dao is constantly nameless” (“道恒名”), see (Gao 2013) Gao Ming高明. Boshu Laozi jiaozhu帛书老子校注, Beijing: Zhonghua shuju中华书局. 
yet are not motivated in doing so. Persons who are most appropriate (yi) do things coercively and indeed do have a motive for doing so. Persons who are exemplars of ritual propriety $(l i)$ do things coercively and when no one pays them any heed, they yank up their sleeves and drag others along with them. Thus, only when we have lost sight of Dao is there excellence, only when we have lost sight of excellence is there authoritative conduct, only when we have lost sight of authoritative conduct is their appropriateness, and only when we have lost sight of appropriateness is their ritual propriety. As for ritual propriety, it is the thinnest veneer of doing one's best and making good on one's word, and it is the first sign of trouble. "Foreknowing" is tinsel decorating the way and is the first sign of ignorance. It is for this reason that persons of consequence: set store by the substance rather than the veneer and by the fruit rather than the flower. Hence, eschewing one they take the other.

The more things are external and enforced, the less they occur naturally. In other words, the more we have moral qualities imposing us to act in certain ways, the less the things have the ability to "act on their own authority". To use the terminology proposed by the Laozi, when things are done coercively (youwei 有), appropriated or ritualized, they do not occur on their own.

Authoritative conduct (ren 仁), appropriateness (yi) and ritual propriety (li) are defining things in the manner that they tell us how to act and when. The Daoists, on the other hand, prefer Dao that has no form, or in other words-does not limit the beings to a certain course, but allows them to follow their own natural ways. The passage above gives us two levels of 'virtue' (de德), upper (shangde上 德) and lower (xiade下德). While in the state of the 'most excellent' (upper virtue), the actions are non-coercive and not motivated by external forces. Once that is lost and we arrive at the state of the 'lower virtue', things may be non-coercive, but there is an intention-an external force motivating this type of action. ${ }^{30}$ It is this situation of 'lower virtue' (least excellent) that leads to the moral deterioration described in terms of 'authoritative conduce', 'appropriateness', and 'ritual propriety'.

The elevation of the ethical virtues such as authoritative conduct, appropriateness, and ritual propriety are thus, at the same time, the eradication of the ' $z i$-constructions'. However, it is the $z i$-constructions that allow the things (wanwu物) and the common people ( $m i n$ 民) their authenticity. Thus, for the Daoists, the utmost ethical practice is one where the sages, similar to Dao, do not impose, do not coerce, do not give orders, and do not inflict their own desires on others:

Hence in the words of the sages: we do things non-coercively and the common people develop along their own lines (zihua自化); we cherish equilibrium and the common people order themselves (zizheng自正); we are non-interfering in our governance (wushi 事) and the common people prosper themselves (zifu自富); we are objectless in our desires (wuyu欲) and the common people are of themselves like unworked wood (zipu 自朴). (Chapter 57)

Dao gives the ruler a model for action, but the ruler's authority does not merely come from hierarchy, or from him being the sage who understands Dao to its fullest. His authority must come from the people, and in this sense, it is because the sage is able to enact traits of Dao such as "not managing, claiming or lording" that he can become a ruler. In other words, it is precisely due to the fact that under this type of government the people can be authentic and flourish on their own that the ruler gains his authority. The ideal traits of Dao are expressed in governmental modes of action exhibited through concepts such as "non-coercive action", "cherishing equilibrium", "non-interfering in our governance", and "objectless in our desires". Actions of this sort do not attempt to exercise excessive control over common people, they bring to their "self-flourishing", as expressed in the terms

30 According to Lin Xiyi's 林希逸 (1193-1271 AD) commentary. The character 'yi以' means 'purposefully'. 'wuyiwei' (以) then means that something is done without intentions. See (Chen 2016, p. 215). 
"developing along their own lines", "ordering themselves", "prospering themselves", and being like "unworked wood". 31

The parallel between Dao and the ruler in these passages allows the reader to sense that if the ruler understands the way the world works and what role Dao functions as in regard to the things, then he can emulate this role and lead the state into a situation where it develops in the most efficacious way. The ideal state according to Daoist philosophy is a state of simplicity. This is seen throughout the Laozi in various passages, using different descriptions and words to demonstrate how the sage ruler praises the simple over the complex, the internal over the external. One example that appears twice in the text is that the ruler strives to "fill their bellies" while emptying their "heart-minds". This does not merely mean that the ruler takes care of the basic needs of the people, but also reminds us that the ultimate concern is internal and not external. Chapter 12 reminds us that the external (especially when in excess) brings to confusion and madness:

The five colors blind the eye, the hard riding of the hunt addles both heart and mind, property hard to come by subverts proper conduct, the five flavors destroy the palate, and the five notes impair the ear. It is for this reason that in the proper governing by the sages: the exert their efforts on behalf of the abdomen rather than the eye. Thus, eschewing one they take the other.

The phrase "exert their efforts on behalf of the abdomen rather than the eye" is precisely the concern for the internal over the external. The passage also repeats Chapter 3 where it tells us that "property hard to come by subverts proper conduct" (or, in the case of Chapter 3, "causes the people to become thieves and robbers"). Repetition in short texts such as the Laozi is not something to be taken for granted, but rather, used in different contexts, it reminds the reader the importance of certain principles. The principle of maintaining simplicity among the people and in the kingdom is not only essential for promoting better behavior and maintaining ethical conduct, but also serves as a remedy against extravagant behaviors of rulers who took advantage of their position and held extreme wealth. Thus, authority is not given by exercising control, by being in higher hierarchal position, or even by having more than others. The ruler the Laozi sought for was not necessarily a person born into a royal family, was not necessarily part of an elite, and was not even necessarily a charismatic leader with strong ambitions. It was a person who could maintain simplicity, nurture people by making sure their basic and internal needs were taken care of without trying to exert control over them, it was a person who emulates Dao and the principles of its actions, it was someone who gained authority over the people through allowing their authentic selves to emerge and flourish. They do not control but they do assist through giving the right conditions:

Hence because the sages do things non-coercively they do not ruin them, and because they do not try to control things, they do not lose them. The common people always ruin things they do, just on the very brink of success. Thus, it is said: if you are as careful at the end as you are at the start, you will be free of failure. It is for this reason the sages in leaving off desiring do not prize property that is hard to come by, and in studying not to study, return to what most people have passed over. Although they are quite capable of helping all things follow their own course (ziran 自然), they would not think of doing so. (Chapter 64)

While the ruler is capable of helping the people follow their own course, he does not do so, for if he would, this would not be an authentic course. The ideal ruler, just like the ideal cosmological

31 The term $p u$ 朴 which literally means 'simplicity', is translated in many cases to 'unworked wood'. In Daoist thought, unworked wood is a metaphor for simplicity as it serves as the raw material which has yet been worked on or brought to a certain defined form and function. This metaphor goes beyond mere simplicity as it incorporates a much broader meaning in the sense where it is something undefined and formless without inflicting external restrictions. Thus, the undefined and formless is more flexible and original, or more 'authentic' in the sense where it is not forced to become a defined entity. 
generative force, is one that that secures existence but does not interfere in its development. Dao or the ruler do not ruin things by imposing on them, they do not control and therefore, not only do they win over the world and never lose it, they also gain a world that beholds unique particularities who reach their utmost potential and never cease to generate anew.

\section{Conclusions}

On the cosmological level, Dao, as the forbearer of all things, is always in relation to them while they exist in the world. This does not mean that Dao depends on them for its existence, as well known, Dao generates every being and thing in this world-including great things such as heaven and earth and all other cosmological phenomena. Before the generation of anything, Dao resides in a state of $w u$-an absence of a universe and absence of any type of you. However, Dao does not arrest in this state of $w u$, it generates, develops, grows, nourishes, rears and guards. Once it generates, Dao is in the state of you. Going back and forth in cyclical movements between wu and you is how Dao functions, and it is also how the world is ever new. Therefore, when we attempt to talk about Dao, we need to bring into account both aspects of $w u$ and you and the relationship between them. The question then is, what does the relationship between $w u$ and you have to offer to the relationship between $w u$ and $z i$ ?

As mentioned in the first section, $w u$ offers the function while you offers the benefits. $W u$ as function appertains the political sphere as well. The ruler, the one residing in the state of $w u$, as seen in notions such as wuzhi, wushi, wuyu etc., serves an ultimate social function-the function of authority. As absence $(w u)$ enhances presence (you), the notions of absence attributed to the behavior of the ruler, enhances the presence of the people. In other words, without the $w u$ of the ruler, there is no space left for the $z i$ (authenticity) of the people. The cosmological and metaphysical function of $w u$ in its relation to you not only shows us how the world functions, but also serve as a basis for understand how we, as part of this cosmos, can organize a society in which every single being has a place, and in which every particularity can develop their own course.

Thus, $w u$ and you on the cosmological and metaphysical level are parallel to $w u$ and $z i$ on the socio-political and concrete level. $W u$ functions both on the metaphysical and on the concrete level. It is always in relation to something-it is not mere absence or an absolute nothingness, but rather a philosophical notion that allows the world, as well as everything in it, to achieve their utmost and flourish on their own terms.

Conflicts of Interest: The author declares no conflict of interest.

\section{References}

Ames, Roger T., and David L. Hall. 2003. Daodejing: Making This Life Significant-A Philosophical Translation. New York: Ballantine Books Press.

Chen, Guying. 2015. Zhongguo Zhexue de Chuangshizhe Laozi Xinlun中国哲学的创始者一老子新论. Beijing: Zhonghua shuju中华书局.

Chen, Guying. 2016. Laozi Jinzhu jinyi 老子今注今译. Beijing: Shangwu Yinshuguan商务印书馆.

Csikszentmihaly, Mihaly. 2014. Flow and the Foundations of Positive Psychology: The Collected Works of Mihaly Csikszentmihalyi. New York: Springer Press.

Feng, Youlan. 1959. Laozi zhexue taolun ji 老子哲学讨论集. Beijing: Zhonghua shuju中华书局.

Feng, Youlan. 1987. Zhongguo Zhexue shi Dagang中国哲学史大纲. Beijing: Shangwu yinshuguan商务印书馆.

Gao, Ming. 2013. Boshu Laozi Jiaozhu帛书老子校注. Beijing: Zhonghua shuju中华书局.

Hansen, Chad. 1992. A Daoist Theory of Chinese Thought: A Philosophical Interpretation. Oxford: Oxford University Press. Hu, Shi. 1987. Zhongguo Zhexue shi Dagang中国哲学史大纲. Beijing: Shangwu yinshuguan商务印书馆, vol. 1.

Lai, Karyn. 2007. Ziran and Wuwei in the Daodejing: An Ethical Assessment. Dao 6: 325-37. [CrossRef]

Moeller, Hans-Georg. 2006. The Philosophy of the Daodejing. New York: Columbia University Press.

Rosemont, Henry, Jr. 2006. Explorations in Early Chinese Cosmology. Journal of the American Academy of Religion Studies L/2: 11-65. 
Slingerland, Edward. 2003. Effortless Action: Wu-wei as Conceptual Metaphor and Spiritual Ideal in Early China. Oxford: Oxford University Press.

Slingerland, Edward. 2014. Trying Not to Try: Ancient China, Modern Science, and the Power of Spontaneity. New York: Broadway Books Press.

Wang, Bo. 1991. Laozi Zhexue Zhong Dao He you Wu de Guanxi Shita 老子哲学中 “道” 和 “有”、“无” 的关系试 探. Zhexue Yanjiu哲学研究 8: 38-45.

Wang, Zhongjiang. 2010. Dao yu Shiwu de Ziran: Laozi "Dao Fa Ziran" Shiyi Kaolun道与事物的自然: 老子"道法 自然"实义考论. Zhongguo zhexue 中国哲学 8 .

Wang, Zhongjiang. 2019. Abnormalities and Return: An Exploration of the Concept of Fan 反 in the Laozi. Religions 10: 32. [CrossRef]

Yan, Lingfeng. 1983. Lao Lie Zhuang sanzi yanjiu wenji 老列庄三子研究文集. Taipei: Guoli Bianyi Guan Zhonghua Congshu Bianshen Weiyuanhui国立编译馆中华丛书编审委员会.

2019 by the author. Licensee MDPI, Basel, Switzerland. This article is an open access article distributed under the terms and conditions of the Creative Commons Attribution (CC BY) license (http:// creativecommons.org/licenses/by/4.0/). 